\title{
Toivo Ilmari Wuorenrinne
}

Toivo Ilmari Wuorenrinteen harvinaisen pitkä, liki 92 vuotta kestänyt elämä sammui viime maaliskuun 19. päivänä.

Wuorenrinne syntyi huhtikuun 24. päivänä 1892 Lopella. Hän valmistui filosofian kandidaatiksi historia pääaineenaan 1915. Päätoimisen kansansivistäjän päivätyön hän suoritti Kotkan työväenopiston johtajana (1920-25), Työväen Akatemian rehtorina (1925-38) ja Helsingin työväenopiston rehtorina (193861).

Tänä aikana ja pitkään vielä sen jälkeenkin Wuorenrinne oli mukana monenlaisessa järjestötoiminnassa kansansivistystyön ja muunkin sivistystyön alalla. Niinpä hän toimi Kansanvalistusseurassa sekä valtuuskunnan että johtokunnan jäsenenä ja myös viimeksimainitun pitkäaikaisena puheenjohtajana (1955-74). Hän oli myös Kansanvalistusseuran kirjeopiston johtokunnan puheenjohtajana sekä seuran omistaman Oriveden Opiston johtokunnan jäsenenä.

Vielä pitemmäksi Wuorenrinteen toiminta muodostui Kansalais- ja työväenopistojen liiton hallinnossa. Hän tuli liiton toimikunnan jäseneksi 1924, puheenjohtajaksi 1938 ja hoiti tätä tehtävää vuoteen 1961 asti. Hän oli myös mukana perustettaessa nykyistä Opistolehteä Kotkassa 1923 ja toimi sen päätoimittajana vuoteen 1961.

Wuorenrinne oli Kansansivistysopillisen yhdistyksen (nykyisen Aikuiskasvatuksen tutkimusseuran) perustajajäsen ja toimi sen ensimmäisenä esimiehenä vuoteen 1954 asti.

Lyhyesti mainittakoon, että Wuorenrinne toimi myös teatteri- ja lausuntataiteen aloilla.

Monista käytännön toimista huolimatta Wuorenrinteeltä liikeni aikaa myös kirjalliseen työhön. Useimmat hänen julkaisunsa käsittelevät lausuntataidetta ja teatteria, mutta hän kirjoitti myös kansansivistystyötä koskevia artikkeleja. Osa niistä on koottu teokseen Taisteleva kansansivistystyö (1952).

Wuorenrinteen osaksi tuli useita kunnianosoituksia tunnustuksena ansiokkaasta toiminnasta. Muun muassa hänelle myönnettiin kouluneuvoksen ja myöhemmin professorin arvonimi sekä hänet valittiin Kansansivistysopillisen yhdistyksen kunniajäseneksi 1955.

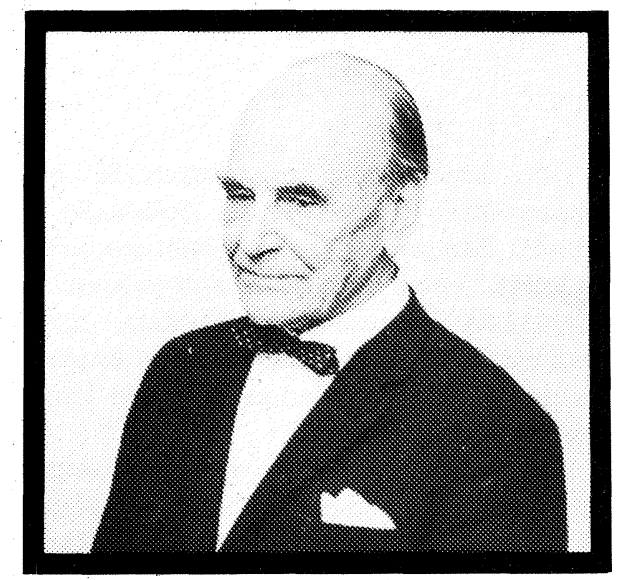

Wuorenrinne oli myös alansa teoreettinen pohdiskelija. Selvittäessään vapaan kansansivistystyön olemusta hän otti lähtökohdaksi sivistyksen käsitteen. Yhtyen kunnioittamansa Zachris Castrénin näkemykseen hän tähdensi, että sivistyksen tarkoitus on monipuolisempi ja syvempi kuin valistuksen. Valistus oli keskeinen käsite siinä kehitysvaiheessa, jolloin puhuttiin vapaasta ja vapaaehtoisesta kansanvalistustyöstä. Kun valistus tähtäsi pääasiassa ihmisen tietopuoliseen kehittämiseen, sivistys pyrki myös tunne-elämän sekä tapojen ja käytöksen jalostamiseen.

Wuorenrinne korosti myös, että vapaata kansansivistystyötä ei saa alistaa minkäänlaisen agitaation tai propagandan välineeksi. Kansansivistystyössä ei saa väistää yhteiskunnallisia ja poliittisia kysymyksiä, mutta sitä ei saa tehdä puoluepolitiikan palvelijaksi, eikä minkään uskonnollisen tai uskonnonvastaisen suunnan välikappaleeksi. Tässä merkityksessä kansansivistystyö on vapaata, puolueetonta ja tunnustuksetonta. Siksi sen perusasennetta voi nimittää myös tieteenomaiseksi.

Näin ollen Wuorenrinne on ollut kannattamassa ja kehittämässä sitä suurta traditiota, joka pitää aikıiskasvatuksen perustana humanismia. 
Kansansivistystyön teoreettisessa mietiskelyssä Wuorenrinne tukeutui ennen kaikkea saksankieliseen kirjallisuuteen. Hän kävi myös Saksassa ja Itävallassa tutustumassa niin kansansivistystyön käytäntöön kuin sen teoreettiseen tutkimukseenkin.

Kun Castrén luopui kansansivistysopin tuntiopettajan tehtävästä Yhteiskunnallisessa Korkeakoulussa, oli luonnollista, että Wuorenrinne asiantuntemuksensa vuoksi tuli hänen seuraajakseen (1938-40).

Tulin tuntemaan Wuorenrinteen 1930-luvun loppupuolella opettajani J.E. Salomaan välityksellä. Sen jälkeen tapasin hänet monissa yhteyksissä, kuten Kansansivistysopillisessa yhdistyksessä perustamiskokouksesta alkaen, toimiessani filosofian luentopiirin ohjaajana Helsingin työväenopistossa ja ennen kaikkea Kansanvalistusseurassa.

Wuorenrinne oli valoisa persoonallisuus, ystävällinen ja sydämellinen ihminen. Hänessä oli myös tarmoa ja temperamenttia. Hän us- kalsi ottaa lujankin kannan oikeana pitämässään asiassa, ja minusta näytti, että tämä rohkeus hänessä iän mukana vain lisääntyi.

Wuorenrinne oli monipuolisesti sivistynyt ihminen, Goethen ihailija ja tuntija, hämmästyttävän monen Suomen kulttuurihistoriassakin mainitun suomalaisen taiteilijan, kirjailijan ja runoilijan tuttu. Sen vuoksi Wuorenrinteen kanssa oli mielenkiintoista ja opettavaista jutustella.

Wuorenrinne oli myös iloinen ja hauska ihminen, taitava juttujen ja vitsien kertoja. Tämä puoli hänestä tuli näkyviini varsinkin Kansanvalistusseuran johtokunnan kokouksissa. Yhtään kokousta ei aloitettu virallisella asialla, ja virallisenkin asioiden lomassa, silloinkin kun ne olivat vaikeita, suotiin aikaa usein juuri Wuorenrinteen aloitteesta naurua kirvoittavalle jutulle. Kiireen tunnun sijasta näissä kokouksissa oli lämmin inhimillisyyden tuntu.

Muistelen Toivo Ilmari Wuorenrinnettä sekä kunnioittaen että kaivaten.

Urpo Harva 